\title{
Reticulated vitreous carbon as an electrode material
}

\author{
J.M. Friedrich ${ }^{\text {a }}$, C. Ponce-de-León ${ }^{\text {a,* }}{ }^{\text {, G.W. Reade }}{ }^{\text {b }}$, F.C. Walsh ${ }^{\text {a }}$ \\ a Electrochemical Engineering Group, Department of Chemical Engineering, University of Bath, Claverton Down, Bath BA2 7AY, UK \\ ${ }^{\mathrm{b}}$ Regenesys Technologies Limited, OTEF, Aberthaw Power Station, The Leys, Barry, Vale of Glamorgan CF62 4QT, UK
}

Received 10 April 2003; received in revised form 10 July 2003; accepted 18 July 2003

\begin{abstract}
An illustrated review of reticulated vitreous carbon (RVC) as an electrode material is presented. Early uses of RVC were largely restricted to small-scale $\left(<1 \mathrm{~cm}^{3}\right)$ electroanalytical studies in research laboratories. RVC properties of a high ratio of surface area to volume and minimal reactivity over a wide range of process conditions, combined with low cost and easy handling, have resulted in a steady diversification of its applications both in research laboratories and in industry. The physical structure of RVC (in terms of pores per linear inch, strut length, strut thickness and area of the trigonal strut) is examined for 10, 30, 60 and 100 ppi (pores per linear inch) grades using scanning electron microscopy. The accurate measurement of these geometrical values presents both theoretical (in terms of definition of trigonal strut area, beginning and end of single strand) and practical problems (large differences in strut length and thickness in individual samples). Data are presented to show the relationships between geometrical properties. Applications include electroanalytical studies and sensors, metal ion removal, synthesis of organics and Fenton's reagent, $\mathrm{H}_{2} \mathrm{O}_{2}$ production and batteries/fuel cells.
\end{abstract}

(C) 2003 Elsevier B.V. All rights reserved.

Keywords: Reticulated vitreous carbon; Porous electrodes; Three-dimensional electrodes

\section{Introduction}

Three-dimensional electrodes are used to counteract the limitations of the low space-time yield and low normalised space velocity obtained in electrochemical processes with two-dimensional electrodes [1]. A threedimensional electrode can be obtained in a number of ways, including a fluidised bed, a packed bed, or the use of a porous material, such as copper-plated, reticulated polyurethane, nickel mesh, etc. In this paper, the applications and properties of reticulated vitreous carbon (RVC) - a microporous, glassy carbon electrode material - are examined.

Vitreous carbon has a low density, a low thermal expansion, a high corrosion resistance and high thermal and electrical conductivities. RVC is an open-pore foam material of honeycomb structure composed solely of vitreous carbon. It has an exceptionally high void volume, high surface area, rigid structure, low resistance to

\footnotetext{
${ }^{*}$ Corresponding author.
}

fluid flow, and very high resistance to temperatures in non-oxidizing environments.

$\mathrm{RVC}$ is a useful electrode material, particularly where high current densities, low electrical/fluid flow resistance, minimal cell volume loss to electrodes and the ability to hold infused materials within controlled pore sizes are required [1]. The skeletal structure of the material is brittle and needs support and the low volumetric carbon content means that care has to be taken to ensure a uniform potential- and current distribution through the material. The principles of RVC as a threedimensional electrode, together with other carbon materials, have been reviewed [2]. Other RVC applications include: high temperature insulation, filters, storage batteries, scaffolds for biological growth, the manufacture of semiconductors and acoustic control [3-7].

\section{Manufacture and physical properties}

The structure of RVC is achieved by polymerisation of a resin combined with foaming agents, followed by 


\begin{tabular}{|llll|}
\hline \multicolumn{2}{|l|}{ Nomenclature } & \\
& & \\
$A_{\mathrm{e}}$ & Surface area per unit volume $\left(\mathrm{m}^{-1}\right)$ & $F$ & Faraday constant $\left(\mathrm{C} \mathrm{mol}^{-1}\right)$ \\
$a$ & Geometrical factor & $I_{\mathrm{L}}$ & Limiting current $(\mathrm{A})$ \\
$b$ & Velocity exponent & $k_{\mathrm{m}}$ & Mass transport coefficient $\left(\mathrm{cm} \mathrm{s}^{-1}\right)$ \\
$c$ & Concentration $\left(\mathrm{mol} \mathrm{l}^{-1}\right)$ & $V_{\mathrm{e}}$ & Volume of the electrode $\left(\mathrm{cm}^{3}\right)$ \\
$E$ & Potential & $v$ & Electrolyte velocity $\left(\mathrm{m} \mathrm{s}^{-1}\right)$ \\
$E_{1 / 2}$ & Half-wave potential & $z$ & Number of electrons transferred \\
\hline
\end{tabular}

carbonisation. The result is a low volume disordered glassy porous carbon with some crystallographic order, low electrical resistance and a continuous skeletal structure. Classically, polyurethane and phenolic resins are used although furfuryl and epoxy resins can also be used; these have $3 \%$ and $50 \%$ 'carbon yield', respectively. The foam resin is, typically, dried and cured at $120^{\circ} \mathrm{C}$ then carbonised at $700-1100{ }^{\circ} \mathrm{C}$. Important process variables include the concentration of resin, the type of solvent, the solution viscosity, the concentration of curing agents, the precursor foam pore size and the firing temperature. Glassy porous carbon can also be obtained from high molar mass thermoplastic carbons (pitch) [8]. During the production of RVC, a linear shrinkage of approximately $30 \%$ occurs.

Reticulated vitreous carbon has a free void volume between $90 \%$ and $97 \%$, depending on the ppi grade, and a surface area of $\cong 65 \mathrm{~cm}^{2} \mathrm{~cm}^{-3}$, for the $100 \mathrm{ppi}$

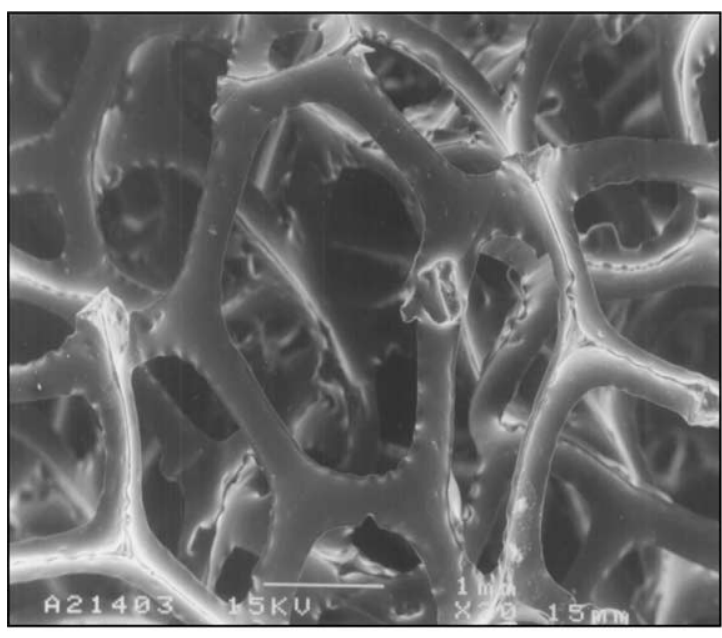

(a) $1 \mathrm{~mm}$

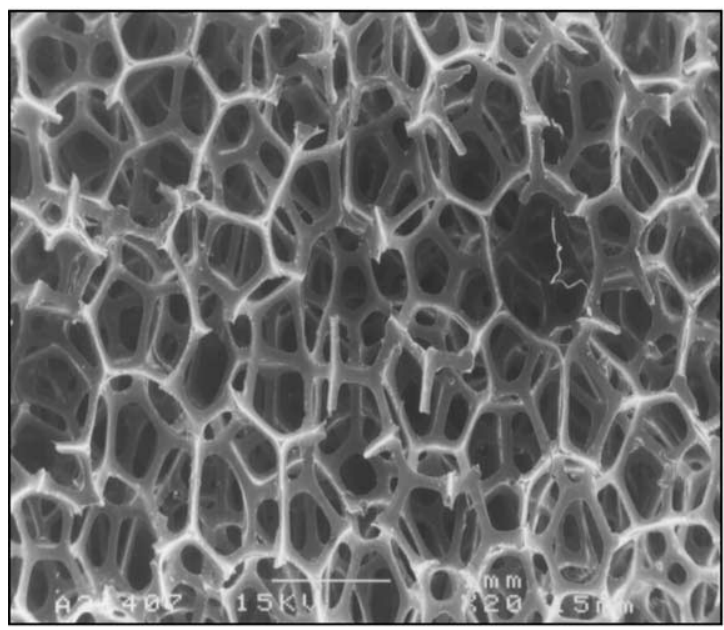

(c) $1 \mathrm{~mm}$

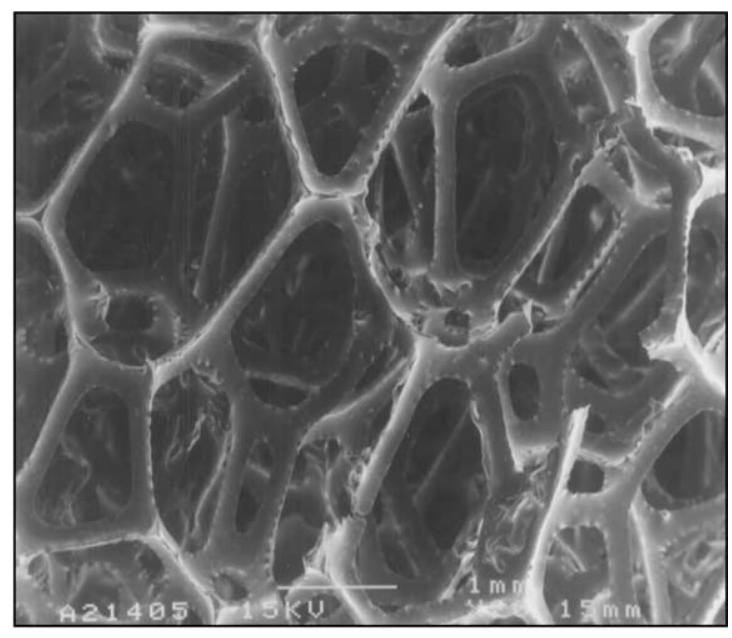

(b) $1 \mathrm{~mm}$

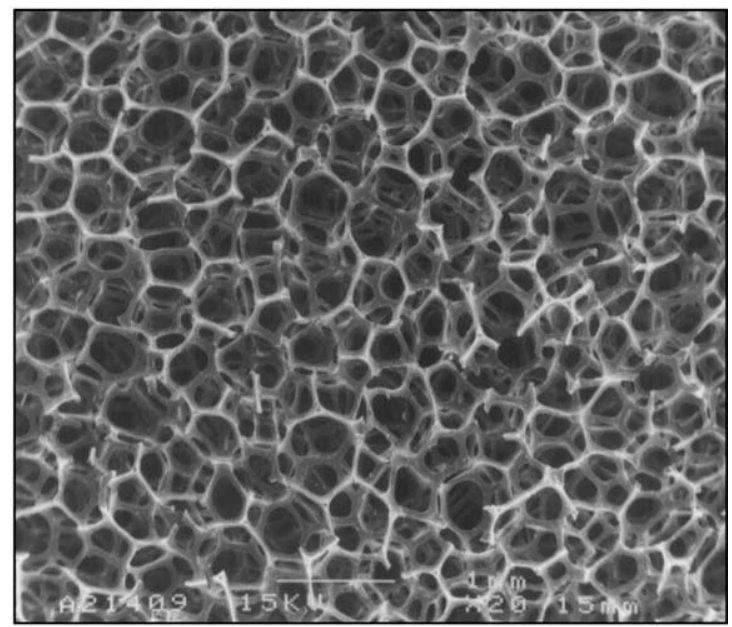

(d) $1 \mathrm{~mm}$

Fig. 1. SEM micrographs of: (a) 10, (b) 30, (c) 60 and (d) 100 ppi (nominal pores per linear inch) RVC samples. Closeups of struts for: (e) 10, (f) 30 and (g) 100 ppi RVC samples. 


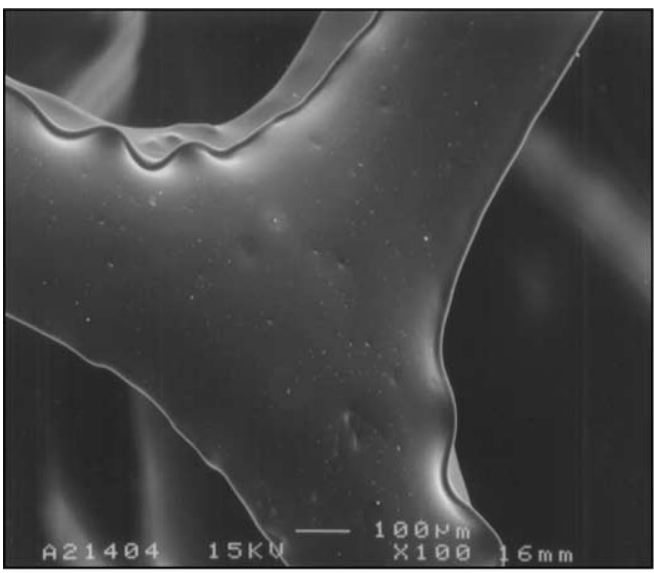

(e) $100 \mu \mathrm{m}$

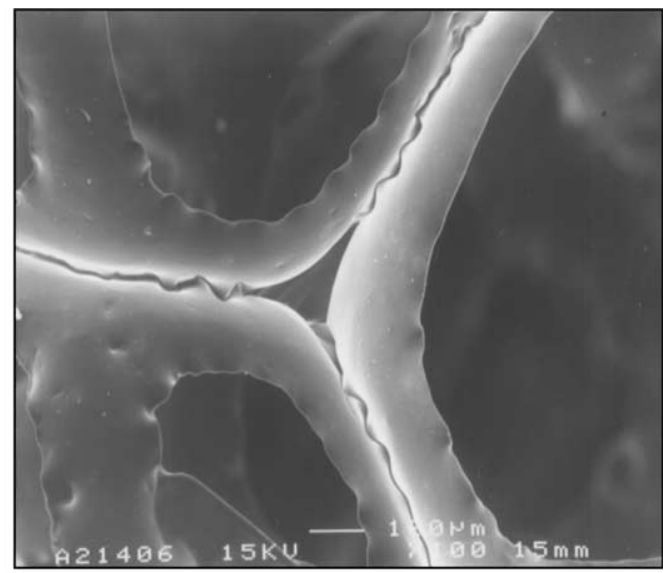

(f) $100 \mu \mathrm{m}-$

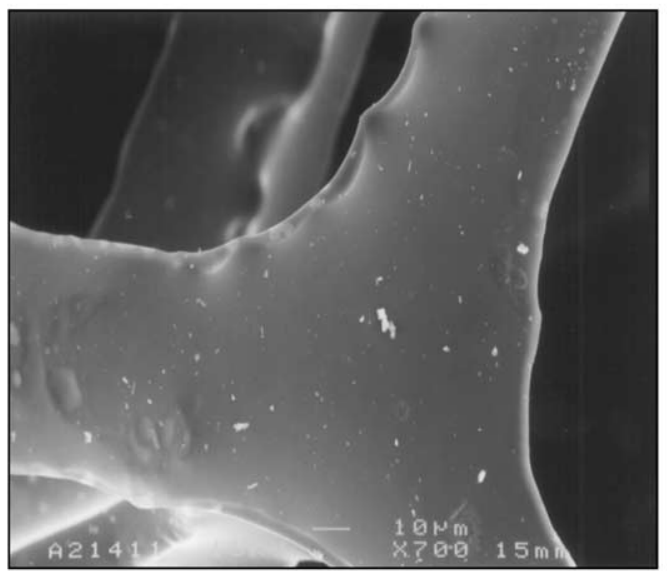

(g) $100 \mu \mathrm{m}$

Fig. 1. (continued)

grade [3]. RVC does not combust after heating to bright incandescence in air followed by removal of the heat source. However, heating above $315{ }^{\circ} \mathrm{C}$ in air results in significant oxidation, producing a material with enhanced adsorption properties. It is highly resistant to intercalation by materials that disintegrate graphite and it is inert to a wide range of very reactive acids, bases, and organic solvents. RVC material can be obtained from suppliers offering a wide range of instruments and supplies for electrochemical applications [9].

The pressure drop of a flowing stream across an RVC structure is small. The honeycomb structure, shown in Fig. 1(a)-(c) for 10, 30, 60 and 100 ppi samples, is formed by strands of carbon, also called struts (see Fig. 1(e) and (f)) that form a so-called trigonal strut, which appears like a triangle from above but is in fact more like a tetrahedron, with one of the strands hidden out of view under the others. Replication of this arrangement gives rigid structure to the $\mathrm{RVC}$. In order to characterise the structure of a particular sample of RVC foam four variables need to be taken into account, these are the number of pores per linear inch (ppi), the strut length, the strut thickness and the surface area of the trigonal strut, the area where the struts meet. Using the images obtained by scanning electron microscopy (SEM), the lengths and widths of the carbon struts as well as the areas of the trigonal struts were determined for 10, 30, 60 and 100 ppi RVC samples. The strut length was measured from the end of the trigonal struts on either side, where the strand thickness was uniform and no longer influenced by the trigonal struts, as it is shown in Fig. 2(a). Similarly, for the strut thickness, the measurements were taken at the middle of a carbon strut between two trigonal struts. Fig. 2(b) shows the circle that approximated the strut area. The area of this circle was determined and set equal to the area of the trigonal strut. While this may not be entirely exact, it gives a reasonably accurate and reproducible measurement of the trigonal strut area.

The struts in a sample of RVC can vary considerably in length and width, as can be seen from the figures. The accuracy of the measurements is hampered by the need to define clearly where the transition from trigonal to 


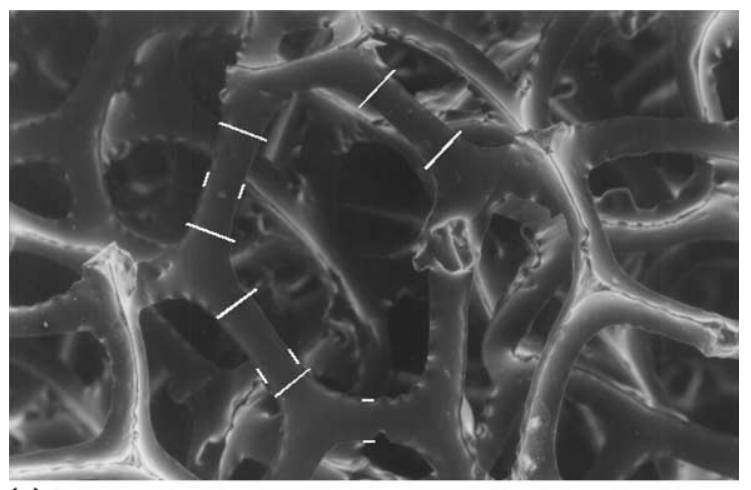

(a) $1 \mathrm{~mm}$

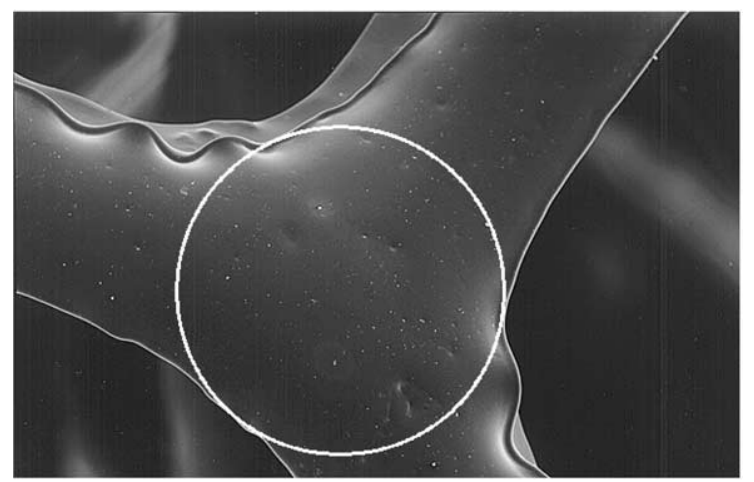

(b) $100 \mu \mathrm{m} \longrightarrow$

Fig. 2. SEM micrograph of: (a) 10 ppi RVC, the white lines mark the end-points of length and thickness measurements made to obtain the data in Table 1. (b) SEM micrograph of a 10 ppi RVC sample. The white circle marks the region used to calculate the area of the trigonal strut.

single strut takes place. To compensate for this, the data were averaged from several measurements of length, strut thickness and circle radius for each porosity.

The measured values obtained from Fig. 2 are shown in Table 1 and plotted in Fig. 3. At higher ppi grades, the strands become both shorter and thinner. At the same time, the trigonal strut radius and the strut thickness have, as was to be expected, very similar values. The slight kink in the data for the strut length of the $10 \mathrm{ppi}$ foam, is most probably due to the difficulties presented by the material structure and the measurement itself, as outlined above.

The specific surface area, $A_{\mathrm{e}}$, for 10, 20, 50,60, 80 and 100 ppi was calculated from SEM images by measuring the struts and circle areas in a defined area of the RVC sample. Fig. 4 shows the calculated specific surface area $A_{\mathrm{e}}$ vs. porosity, the linear equation of this plot for a 100 ppi material corresponds to a volumetric surface area of approximately $65 \mathrm{~cm}^{2} \mathrm{~cm}^{-3}$. This value agrees well with those reported in the literature using pressure drop measurements [10], and with the manufactured specifications available from Materials and Aerospace, Oakland, CA [11].

\section{Electrochemical cell design for RVC electrodes}

The large surface area and the high porosity of the RVC material has attracted great interest, as potentially, high rates of conversion per unit volume can be achieved. The design of the electrochemical cell for an RVC electrode should allow for uniform current and potential distribution, low ohmic internal resistance and high rates of mass transport of the electroactive species to the electrode surface. This can be achieved if the electrode is sufficiently thin for the voltage to be taken as constant and the distribution of the reaction current uniform over the electrode surface. The limitations of conversion rate and maximum allowable potential drop in a porous electrode, to prevent side reactions are well documented in the literature $[1-3,5,10,12,13]$. Under mass transport limitations, the overall performance of a cell can be written in terms of the average mass transport coefficient, $k_{\mathrm{m}}$ :

$I_{\mathrm{L}}=z F k_{\mathrm{m}} A_{\mathrm{e}} c$,

where $I_{\mathrm{L}}, z, F, A_{\mathrm{e}}$ and $c$, are the limiting current, number of electrons transferred, Faraday constant $(96,485 \mathrm{C}$ $\mathrm{mol}^{-1}$ ), electrode area per unit electrode volume and bulk concentration of electroactive species in the electrolyte, respectively. The mass transport properties are usually discussed in terms of the dimensionless numbers, Reynolds, Sherwood and Schmidt [12,13]. For a particular electrolyte and electrode material at constant temperature the mass transport coefficient can be expressed as

$k_{\mathrm{m}} A_{\mathrm{e}}=a^{*} v^{b}$,

where $v$ is the electrolyte velocity; $a^{*}$ and $b$ depend on electrode shape and type of flow, respectively: $0.3<$ $b<0.5$ for laminar flow and $0.45<b<0.8$ for turbulent flow.

Table 1

Dimensions of the physical characteristics of four grades of RVC foams (taken from scanning electron optical micrographs)

\begin{tabular}{lllll}
\hline Property & \multicolumn{2}{l}{ Nominal pores per linear inch (ppi) } \\
\cline { 2 - 4 } & 10 & 30 & 60 & 100 \\
\hline Strut length $(\mathrm{mm})$ & 0.810 & 0.686 & 0.250 & 0.130 \\
Strut thickness $(\mathrm{mm})$ & 0.316 & 0.160 & 0.073 & 0.050 \\
Trigonal strut circle radius $(\mathrm{mm})$ & 0.225 & 0.157 & 0.071 & 0.041 \\
Trigonal strut area $\left(\mathrm{mm}^{2}\right)$ & 0.159 & 0.077 & 0.016 & 0.005 \\
\hline
\end{tabular}




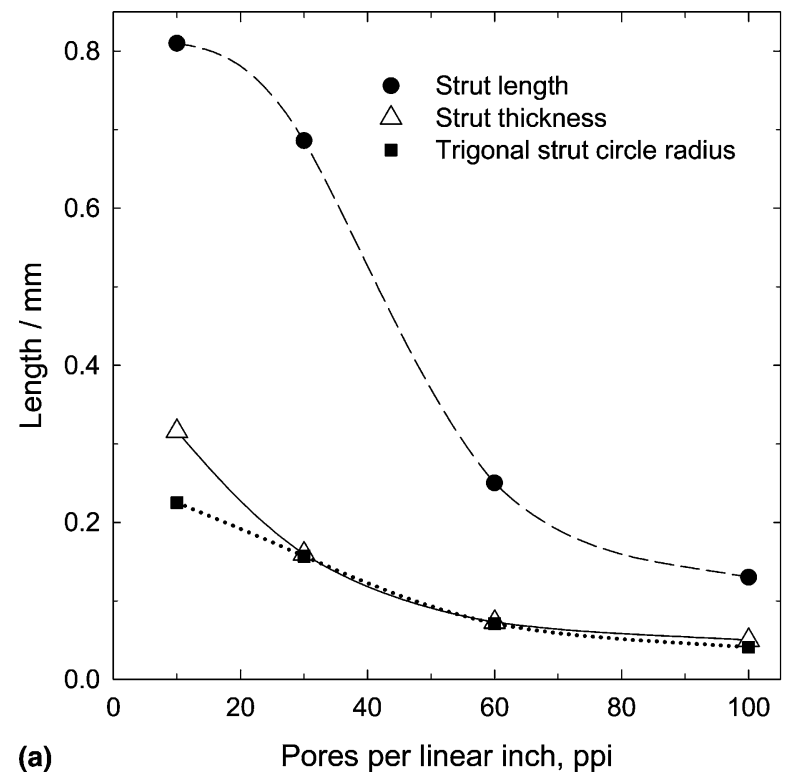

Fig. 3. (a) Strut dimension vs. pores per linear inch. (b) Strut area vs. pores per linear inch.

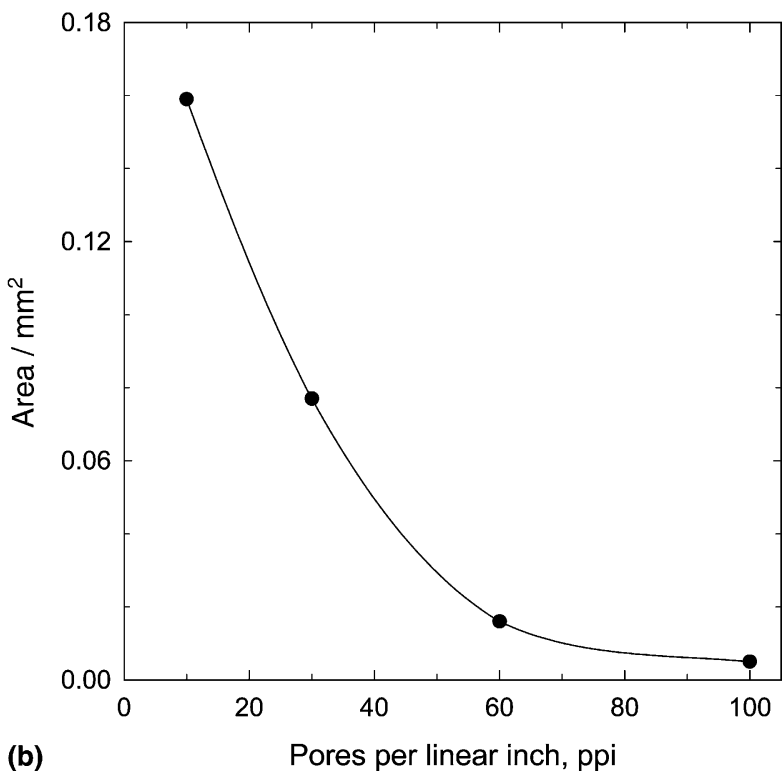

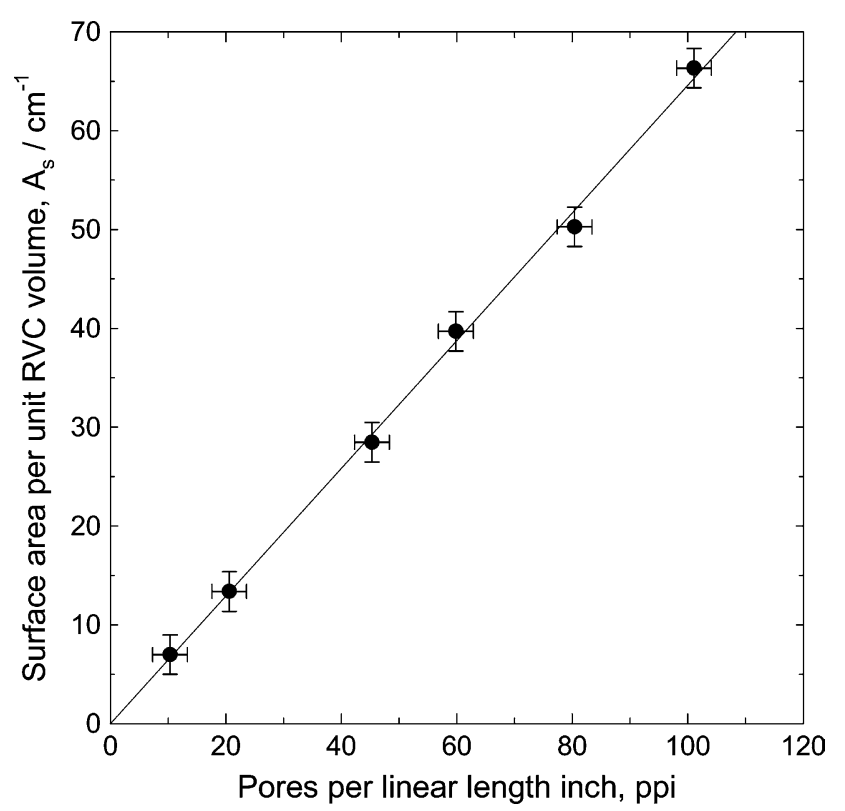

Fig. 4. Electrode area per unit electrode volume vs. porosity grade of RVC (data obtained from scanning electron microscopy).

Most electrochemical reactors operate in a mode that can be approximated to three modes of operation: (1) the simple batch reactor, SBR, (2) the plug flow reactor, PFR, and (3) the continuously stirred tank reactor, CSTR [12,13]. Electrochemical cells performance at a particular point in time, space or area is assessed by their figures of Merit: yield, fractional conversion, current efficiency, overall selectivity, cell voltage, active electrode area per electrode volume, space-time and space-time yield [12-14]. Electrochemical cells with RVC electrodes include stationary and moving elec- trodes in flow-through and flow-by configurations. Fig. 5(a) shows an electrochemical cell using an RVC electrode in the flow-through configuration; the electrolyte and current flow are parallel. This mode of operation has been used in many electrochemical applications [15-21]. Fig. 5(b) shows another electrochemical cell in the flow-by configuration; in this case the electrolyte flow is perpendicular to the current flow. The cell, originally designed by Walsh and constructed by Marshall, consisted of four blocks of polypropylene (A, B, C and D) each $280 \mathrm{~mm} \times 100 \mathrm{~mm} \times 12 \mathrm{~mm}$ thick [12]. The steel plate current collector, sunk into one of the inner blocks, held the RVC cathode $(50 \mathrm{~mm} \times 50$ $\mathrm{mm} \times 12 \mathrm{~mm}$ thick) in the centre of the catholyte channel. This configuration has been popular for some large-scale electrochemical applications, e.g., metal ion removal [18,22-26].

Rotating electrodes allow a very efficient design of flow-through electrochemical cells, coupling the large surface area of RVC with the efficient mass-transport of the rotating electrode produces large analytical currents. Using pulsed-rotation techniques to compensate for the background current, well-defined current-potential curves and low detection limits can be achieved [27]. Fig. 5(c) shows a schematic drawing of a rotating cylinder RVC cell which has been used for metal ion removal [28].

\section{Electrochemical applications}

The first use of RVC as an electrode in an optically transparent electrode cell, RVC-OTE, was to study the spectroscopic and electrochemical properties of 

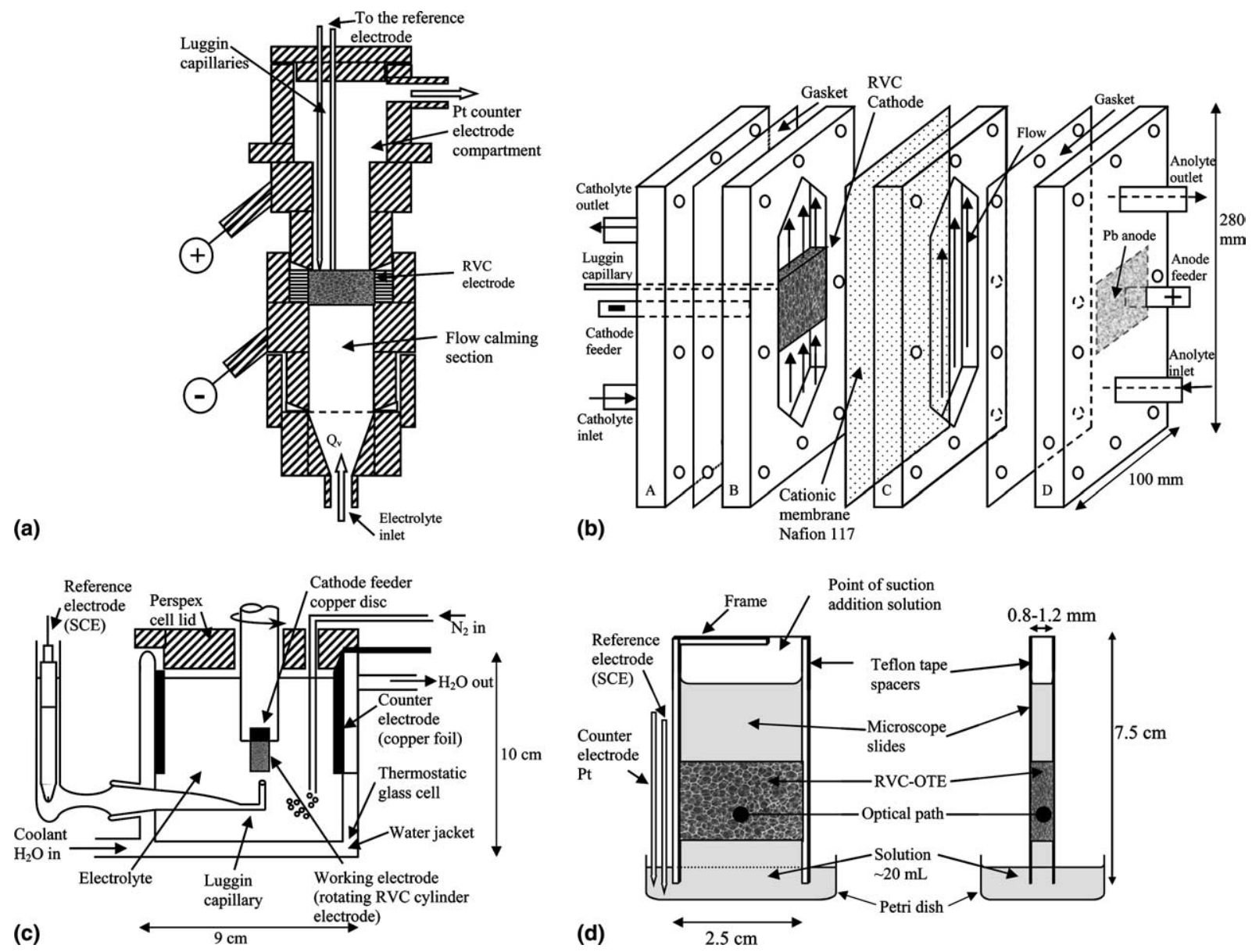

Fig. 5. Electrochemical cells: (a) RVC electrode in the flow-through configuration for potential distribution studies under limiting current conditions [21]. (b) RVC electrode in the flow-by configuration used for the removal of metal ions [22]. (c) Two compartment cell with a rotating RVC cylinder electrode [28]. (d) Optically transparent, thin layer, RVC electrode [29].

$o$-tolidine and $\mathrm{MnO}_{4}^{-}$[29]. The small volume of the cell 400-550 $\mu$ l, Fig. 5(d), allows complete electrolysis in a short period of time. The values of both cathodic and anodic peak currents during the cyclic voltammogram of $4.05 \mathrm{mM} \mathrm{K}_{3} \mathrm{Fe}(\mathrm{CN})_{6}$ solution at $1 \mathrm{mV} \mathrm{s}^{-1}$ were identical indicating negligible diffusion of the electroactive material into the bulk solution. More recently, a similar cell was used for both flow and batch spectro-electrochemical measurements [30]. Over time, other applications have been developed for RVC, these include: sensors, metal ion removal, synthesis of organics, Fenton's reagent for the destruction of organics and energy conversion, among others. The following sections give an overview of these applications.

\section{Electroanalytical studies and sensors}

An early review on RVC, by Wang, appeared in 1981 [3] and predicted increasing applications in analytical chemistry, particularly in sensor development. In an earlier paper, Blaedel and Wang demonstrated the use

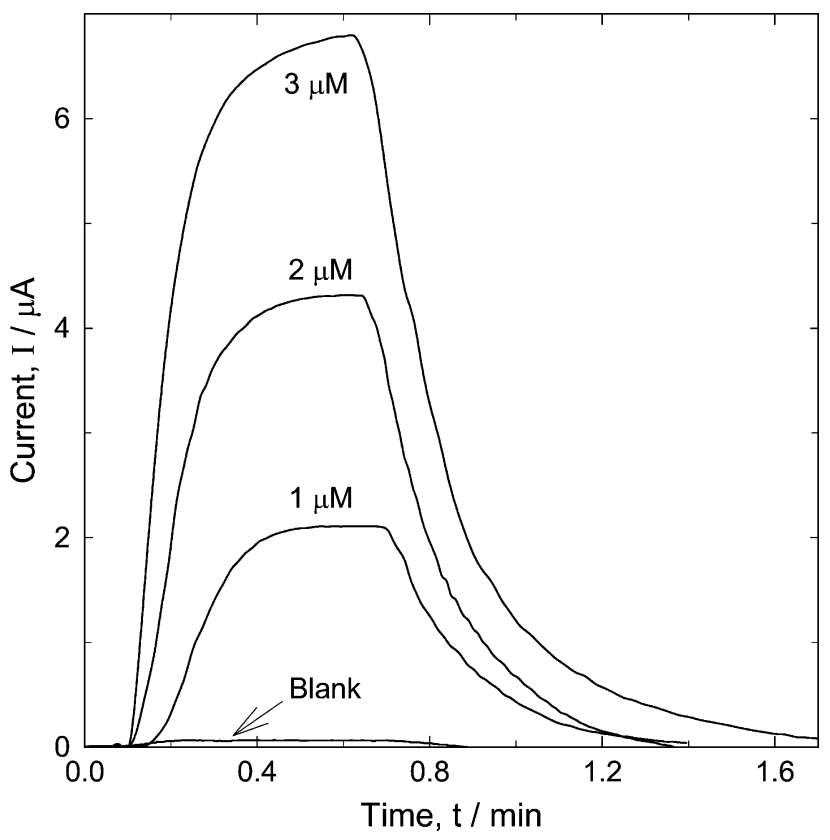

Fig. 6. Pulsed rotation response for $1,2,3 \mu \mathrm{M}$ ascorbic acid at a constant flow rate of $2.25 \mathrm{ml} \mathrm{min}{ }^{-1}$ in a $0.1 \mathrm{M}$ phosphate buffer. RVC thickness was $1.8 \mathrm{~mm}$. Applied potential $+0.75 \mathrm{~V}$ vs. $\mathrm{Ag} \mid \mathrm{AgCl}$ [27]. 
of RVC as a sensor [27]. Fig. 6 illustrates their results obtained from a pulse rotation voltammetry technique used in a flow through RVC electrode for the determination of micro molar concentrations of ascorbic acid in $0.1 \mathrm{M}$ phosphate buffer. Through this technique, they were able to detect concentrations of ascorbic acid down to $0.1 \mu \mathrm{M}$. In glucose determination, for example, a number of studies use immobilized enzymes attached to a RVC substrate. Lange and Chambers [31] fabricated and evaluated an electrode to determine glucose in human blood plasma, down to $1.2 \mathrm{mg} \mathrm{m}^{-1}$. The glucose oxidase enzyme and ferrocene couple were trapped in polyacrylamide gel, packed into a strip of RVC. Despite the fact that the chemical stability of the electrode was good, its physical stability in aqueous solutions was limited.

Wieck et al. [32] attached glucose oxidase to a $80 \mathrm{ppi}$ RVC cylinder, both covalently and by adsorption in a flow-through configuration. Their findings suggested that covalent attachment resulted in higher activity for glucose detection. In a further study [33], they measured the concentration of $\mathrm{H}_{2} \mathrm{O}_{2}$, produced by the oxidation of glucose at a constant potential at flow rates from 1 to $4.5 \mathrm{ml} \mathrm{min}{ }^{-1}$. The oxidation currents were linearly correlated to the glucose concentration in the range of $2.5-10 \mathrm{mM}$ only.

Glucose oxidase enzyme was immobilised with glutaraldehyde in a platinized RVC cylinder electrode to measure glucose in human blood serum by flow injection analysis (FIA) by Yacynych et al. [34]. The lifetime of the electrode was claimed to be 1.5-3 months with a throughput of 130 samples per hour. Detection was accurate up to a glucose concentration of $100 \mathrm{mM}$. Similarly, Heider et al. [35] detected glucose on a platinized 80 ppi RVC electrode amperometrically under similar conditions, achieving a detection range of 0.025 $0.1 \mathrm{mM}$. Stopped-flow, linear sweep voltammetry with a RVC cylindrical electrode in a flow-through configuration was used to determine dopamine in the presence of ascorbic acid down to $5 \times 10^{-7} \mathrm{M}$ levels by Tougasand and Curran [36]. On the other hand, Jaraba et al. [37] used 100 ppi RVC, coated with poly(3-methylthiophene), as an enzyme reactor material in a flow injection configuration for the amperometric determination of $\mathrm{L}-$ lactate and NADH. The detection limit was $1 \times 10^{-5} \mathrm{M}$, despite the interference of ethanol, citric, malic and tartaric acids at five times the concentration of lactate and acetic acids at twice the concentration of the analyte.

Saidman and Bessone used RVC and paraffin-coated $\mathrm{RVC}$, among other graphite pastes, for the voltametric determination of $\mathrm{NAD}^{+}$. They observed only oxidation peaks of $\mathrm{NAD}^{+}$in the paraffin-coated RVC [38]. Hrníová, et al. [39] used RVC for the amperometric determination of $\mathrm{NO}_{2}$ in air, using a planar sensor constructed on a glass plate with a solid polymer electrolyte (SPE). They concluded that, compared to an $\mathrm{Au}$ mesh electrode, RVC showed higher sensitivity and stability, better reproducibility and less dependence on the relative humidity; while having inferior dynamic properties; RVC could be used to replace the more expensive noble metal electrodes. Flowers et al. [30] used the reduction of ferricyanide as a model reaction in a spectro-electrochemical cell with a 60 ppi RVC electrode in batch and flow injection analysis arrangements.

\section{Metal ion removal}

Various cell configurations and electrolyte conditions have been studied for the removal of metal ions from aqueous wastewater, using RVC electrodes. The technology competes with traditional methods of wastewater treatment such as precipitation, cementation, solvent extraction and ion exchange. Despite this, the recovery of heavy metals using RVC electrodes can offer a highly efficient and low cost process. Due to the RVC properties, electrolysis yields near $100 \%$ can be achieved, with the electrode still sufficiently porous to allow for low flow resistance after the deposition of metals in comparison to a bed of loose particles [18].

Whyte [10] demonstrated the use of an RVC electrode for the recovery metals in a mixed metal ion solution with initial concentrations of $\approx 10 \mathrm{ppm}$ in a solution of $0.1 \mathrm{M} \mathrm{NaCl}$ at $\mathrm{pH}$ 7. Fig. 7 shows the normalized concentration decay of copper, cadmium and zinc ions. Over the first 60 minutes, a potential of $-0.5 \mathrm{~V}$ vs. SCE

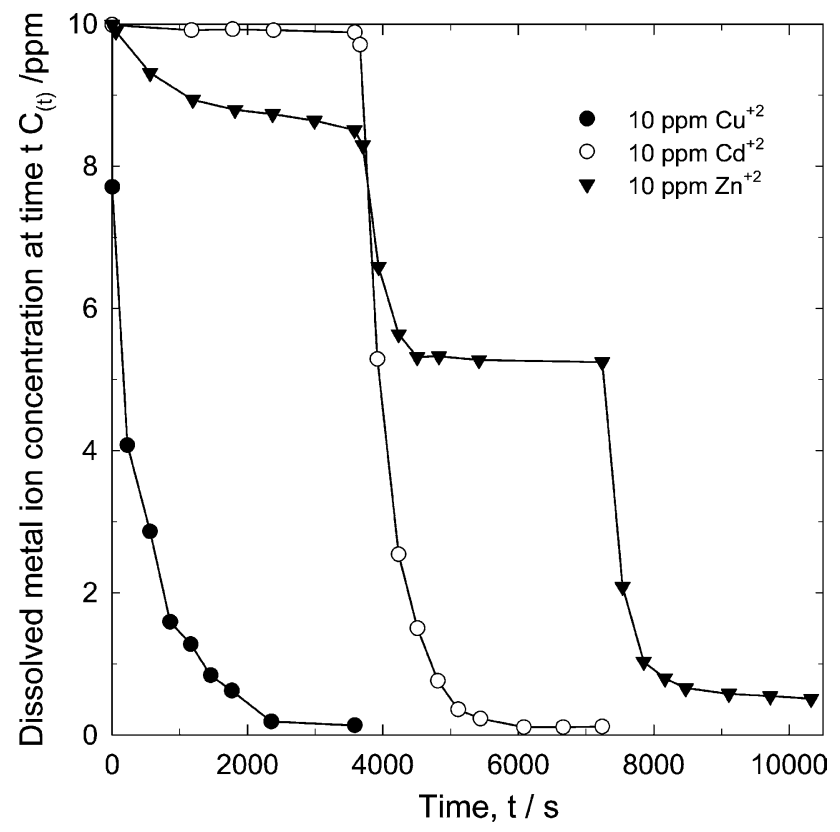

Fig. 7. Concentration decay vs. time for the reduction of $10 \mathrm{ppm}$ of $(\mathbf{\bullet})$ $\mathrm{Cu}^{+2}$, (O) $\mathrm{Cd}^{+2}$ and $(\boldsymbol{\nabla}) \mathrm{Zn}^{+2}$ in a $\mathrm{N}_{2}$ purged $0.1 \mathrm{M} \mathrm{NaCl}, \mathrm{pH} 7$, solution at a 100 ppi RVC electrode. Mean linear velocity $0.083 \mathrm{~m} \mathrm{~s}^{-1}$. Electrode potentials $=-0.5,-1.0$ and $-1.4 \mathrm{~V}$ vs. SCE, $T=298 \mathrm{~K}$ [10]. 
was applied to remove only the $\mathrm{Cu}^{+2}$ ions. This was achieved successfully although $15-20 \%$ removal of $\mathrm{Zn}^{+2}$ ions was noticed at this potential with no change in the $\mathrm{Cd}^{+2}$ level. During the following hour, the potential was changed to $-1.0 \mathrm{~V}$ to remove $\mathrm{Cd}^{+2}$ ions. Cadmium recovery was successful but the removal of $\mathrm{Zn}^{+2}$ reached $50 \%$. The depletion of $\mathrm{Zn}^{+2}$ was achieved by changing the potential to $-1.4 \mathrm{~V}$. The final concentrations were $<0.1,<0.05$ and $<0.5 \mathrm{ppm}$ for $\mathrm{Cu}^{+2}, \mathrm{Cd}^{+2}$ and $\mathrm{Zn}^{+2}$, respectively. Copper and cadmium depletion followed a logarithmic decay indicating mass transport control, however, zinc removal appeared to be more complex, probably due to the formation of hydroxide species evidenced by the increase of $\mathrm{pH}$ of the solution. Studies for the removal of individual metals using $\mathrm{RVC}$ have been published; the following is a profile of published works.

\subsection{Copper deposition}

The deposition of copper has been extensively studied and has been used as a reference for more complex liquors [40]. Copper ions are part of industrial effluents in a number of important processes such as electroplating, circuit-board manufacture and some catalyses; therefore, strong environmental, legal and hence economical pressures on finding efficient ways of effluent cleanup exist. Fig. 8(a) and (b) show SEM micrographs of deposited copper on an RVC electrode, using $0.1 \mathrm{M} \mathrm{NaCl}$ at $\mathrm{pH} 7$ [28]. At this relative high magnification, the crystal features protruding from the electrode surface are over $10 \mu \mathrm{m}$ high. In the higher magnification, Fig. 8(b), the individual crystals appear angular and dendritic. These types of crystal account for the increase in the mass transport coefficient associated with the specific electrode area, $k_{\mathrm{m}} A_{\mathrm{e}}$.

Wang and Dewald [18] examined the use of a cylindrical RVC electrode in a flow-through configuration for metal removal in combination with on-line monitoring of the effluent. They studied the recovery of $\mathrm{Cu}(\mathrm{II})$ in $0.1 \mathrm{M} \mathrm{KNO}_{3}$ among other metals, reporting an efficiency of more than $90 \%$ at potentials negative to $-0.5 \mathrm{~V}$ vs. SCE. Complete $\mathrm{Cu}$ (II) removal was achieved at potentials of -0.9 and $-1.2 \mathrm{~V}$ vs. SCE with lower efficiency. Copper deposits were discontinuous and did not clog the RVC porous even after many successive experiments.

Pletcher et al. [41] used several RVC porosities to remove low levels of $\mathrm{Cu}$ (II) from acidic sulphate media. Fig. 9 shows the logarithmic decay of the normalized copper ion concentration using 10, 30, 60 and $100 \mathrm{ppi}$ RVC electrodes. As was expected, the concentration of copper decays faster as the porosity of the electrode increases. The current efficiency as a function of copper ion concentration for the four grades of RVC was reported to be less than $80 \%$. Low current efficiencies for the higher ppi foams were attributed to difficulties in the

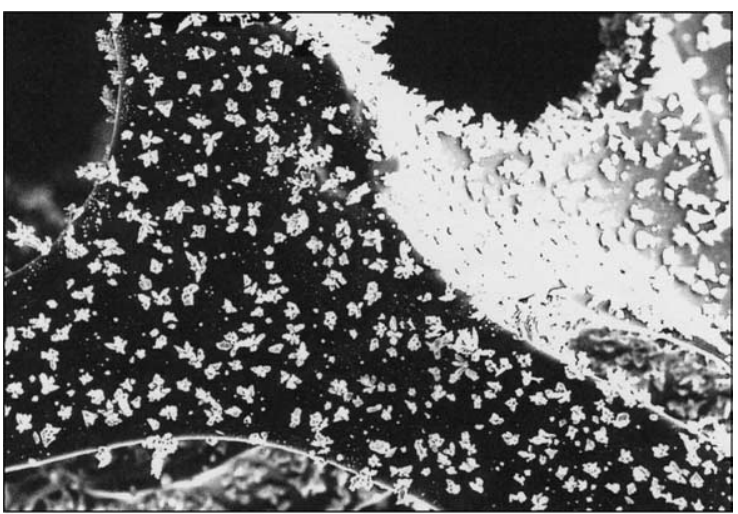

(a) $40 \mu \mathrm{m}$

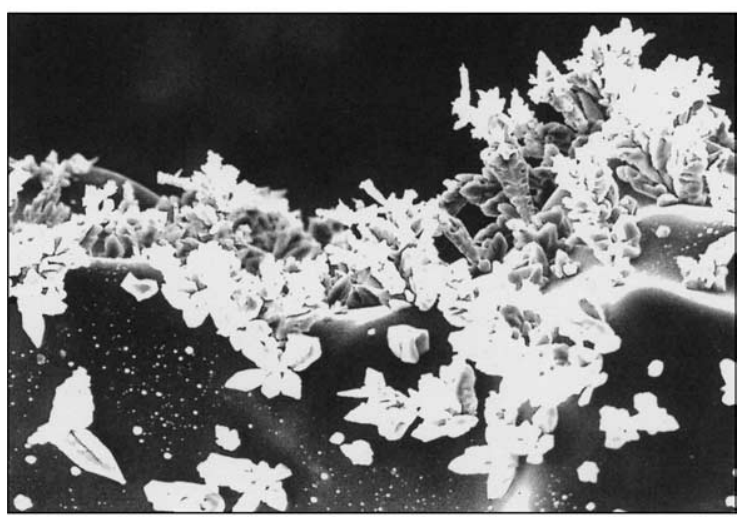

(b) $10 \mu \mathrm{m}$

Fig. 8. Copper deposition onto bare RVC from a solution containing initially $0.5 \mathrm{mM}$ cupric ion in a deoxygenated $0.1 \mathrm{M} \mathrm{NaCl}$, $\mathrm{pH} 7$, solution, $T=298 \mathrm{~K}, \omega=157 \mathrm{rad} \mathrm{s}^{-1}$ (1500 rpm) [28]: (a) 40 and (b) $10 \mu \mathrm{m}$.

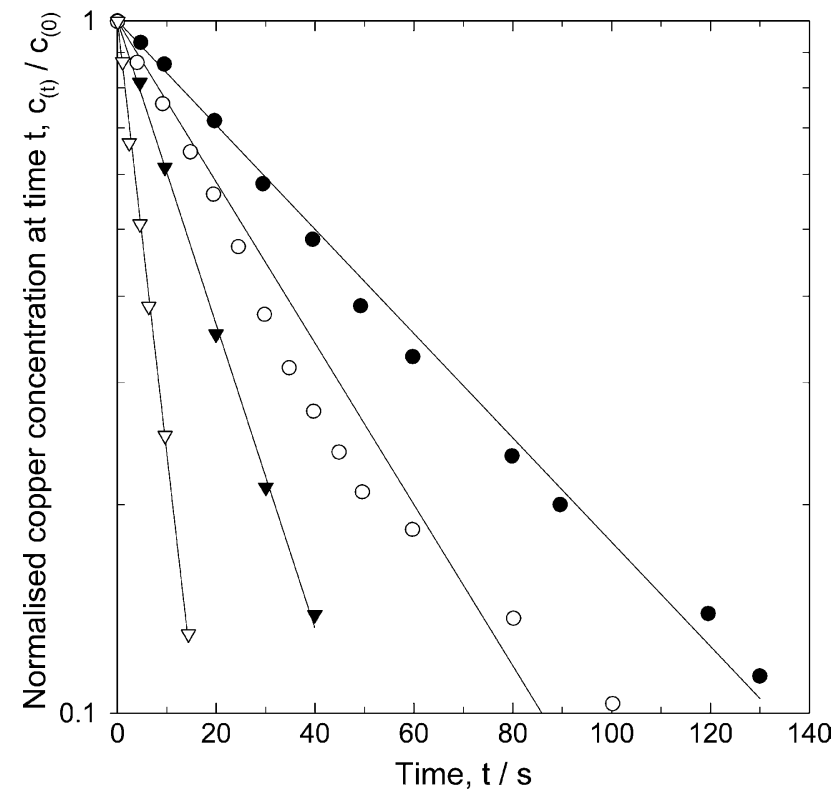

Fig. 9. Logarithm of normalized copper(II) concentration versus time for $(\bullet) 10,(\bigcirc) 30,(\nabla) 60$ and $(\nabla) 100$ ppi reticulated vitreous carbon. Controlled potential electrolysis at -0.5 vs. SCE. $c_{(0)} 0.16 \mathrm{M}(10 \mathrm{ppm})$ $\mathrm{Cu}^{+2}$ in a $\mathrm{N}_{2}$ purged $0.5 \mathrm{M} \mathrm{Na}_{2} \mathrm{SO}_{4}, \mathrm{pH} 2$, solution. Mean linear flow velocity of $0.083 \mathrm{~m} \mathrm{~s}^{-1}$ [40]. 
nucleation of copper or to the reduction of surface oxide. A general trend was that current efficiency was high and constant at large concentrations but fell rapidly at lower cupric ion levels. They also found that air saturation of the solutions had only minor adverse effects on performance while chloride ions and decreasing ionic strength had no adverse effects at all. The normalised space velocity, the power requirement and the energy consumption were more advantageous than those achieved with other three-dimensional electrodes.

Walsh et al. [40] continued their work into $\mathrm{Cu}$ (II) removal from dilute sulphate solutions. They found values of the product of the averaged mass transport coefficient $\left(k_{\mathrm{m}}\right)$ and cathode area per unit electrode area $\left(A_{\mathrm{e}}\right)$ for different RVC grades. They presented detailed numerical data to demonstrate the satisfactory performance of RVC in the chosen system.

Following their previous paper [41], Pletcher et al. [42] examined the performance of a single pass reactor for the removal of $\mathrm{Cu}$ (II) ions using a cell of $400 \mathrm{~mm}$ long $\mathrm{RVC}$ constructed from eight segments controlled independently. This arrangement demonstrated the feasibility of systems with practicable flow rates and efficiencies without the use of recycling or the drawbacks of pressure drop usually associated with flow-by configurations with low porosity electrodes. The results showed that $\mathrm{Cu}$ (II) could be reduced from $10 \mathrm{ppm}$ to $<0.1 \mathrm{ppm}$ in a single pass along the segmental $400 \mathrm{~mm}$ RVC cathode with current efficiencies as high as $69 \%$. The normalised electrolytic energy consumption, [43], was below $30 \mathrm{~W} \mathrm{~h} \mathrm{~m}^{-3}$. Scale-up was found to be possible with cell behaviour being well described by PFR expressions. Podlaha and Fenton [44] carried out a series of mass-transport studies on a single pass, flow-by $\mathrm{RVC}$ reactor. The electrode was effective for the removal of copper ions from dilute solutions, however, plugging of the 45 ppi electrode during longer runs was reported.

Polcaro et al. [45] reported on the effect of dissolved oxygen in the removal of copper from dilute acid solutions. They presented a mathematical model to interpret the influence of $\mathrm{O}_{2}$ during copper deposition and concluded that an increase in flow rate enhanced the current for copper deposition, (a logical consequence of mass transport control). Only a small effect of faradic efficiency was observed. This was attributed to the fact that the reduction of $\mathrm{O}_{2}$ was under mixed control due to mass transport being an important stage in the process for copper deposition. Purging the solution did not appear to yield appreciable benefits, in terms of faradic efficiency. Instead, they suggested that an improved performance could be obtained by minimising the contact surface area between electrolyte and air to limit reabsorption of oxygen during electrolysis.

Fisk and Boyle [46] examined the removal of metals using 10-100 ppi RVC over a wide range of flow rates $\left(0.1-3.21 \mathrm{~min}^{-1}\right)$. They reported on the economics of the application and possible arrangements for a practical effluent treatment system. Both batch and single pass flow systems were examined with current efficiencies for copper deposition up to $39 \%$ for $99.9 \%$ fractional extraction.

\subsection{Lead deposition}

Lead is a major pollutant; environmental legislation has increased pressure on industries such as manufacturers of paints, batteries and some alloys, to reduce their lead effluent levels. Therefore, lead removal has received a great deal of attention in the literature [47]. As well as $\mathrm{Cu}(\mathrm{II})$ and $\mathrm{Ag}(\mathrm{II})$, Wang and Dewald [18] investigated the deposition of $\mathrm{Pb}$ (II) ions onto RVC, coupled with on-line $\mathrm{Pb}(\mathrm{II})$ monitoring. Cleanup efficiency was dependent on the RVC potential. Similar to the results reported for copper, $\mathrm{Pb}$ (II) was completely removed at potentials of -0.9 and $-1.2 \mathrm{~V}$. The deposits were very similar to those observed for copper and silver, i.e., bare areas and a discontinuous deposit.

Berrettoni et al. $[48,49]$ plated a disk and cylinder RVC electrodes with a thin mercury film in order to determine traces of lead by staircase anodic voltammetric stripping technique. This technique allowed higher scan-rates than differential pulse anodic stripping voltammetry, while still retaining the capacity to discriminate against charging currents. RVC was particularly useful in this application; the large electrode area resulted in high sensitivities as large amounts of metal were reduced during the deposition step.

The influence of the anions $\mathrm{Cl}^{-}, \mathrm{NO}_{3}^{-}, \mathrm{ClO}_{4}^{-}, \mathrm{BF}_{4}^{-}$ and $\mathrm{SO}_{4}^{-}$on the removal of $\mathrm{Pb}$ (II) at different temperatures on 10, 60 and 100 ppi RVC electrodes was examined by Ponce-de-León and Pletcher [22]. Pb(II) ions, analysed by an AA technique, could be removed from all the electrolytes down to levels that allowed discharge into rivers and sea. However, the anion in solution had an unexpected influence over the necessary conditions for satisfactory removal of the $\mathrm{Pb}$ (II) ion. Fig. 10 shows the decay in the concentration of $\mathrm{Pb}$ (II) ions in each of the five electrolytes used for an electrolysis carried out with a 60 ppi RVC electrode at potentials in the range of -0.8 to $-0.9 \mathrm{~V}$ at $298 \mathrm{~K}$. For $\mathrm{ClO}_{4}^{-}, \mathrm{BF}_{4}^{-}$and $\mathrm{NO}_{3}^{-}$ media, the $\mathrm{Pb}$ (II) concentration drops smoothly with time to a less than $1 \mathrm{ppm}$, however, the decay is not as fast as in $\mathrm{Cl}^{-}$medium, indicating that lead deposition was not mass transported controlled in these media except for chloride. The removal of $\mathrm{Pb}$ (II) ions from a $\mathrm{SO}_{4}^{-}$medium was much slower at this temperature and only $20 \%$ was removed after $3000 \mathrm{~s}$ of electrolysis. With increase of the temperature to $333 \mathrm{~K}$, the removal of $\mathrm{Pb}$ (II) reached $90 \%$ in $2000-2500 \mathrm{~s}$ (80 s for a fully mass transported controlled electrolysis in chloride medium). The conclusions were that addition of trace chloride ions 


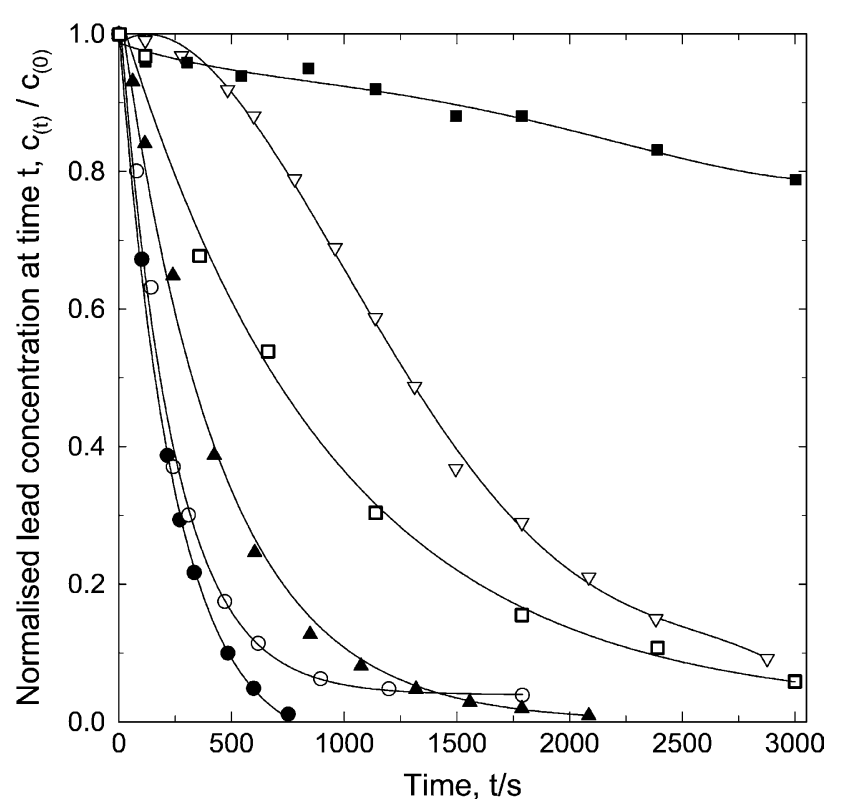

Fig. 10. Normalized concentration of $\mathrm{Pb}(\mathrm{II})$ vs. time for a 60 ppi RVC electrode in $(\bullet) \mathrm{Cl}^{-},(\bigcirc) \mathrm{ClO}_{4}^{-},(\boldsymbol{\Delta}) \mathrm{BF}_{4}^{-},(\nabla) \mathrm{NO}_{3}^{-},(\mathbf{\square}) \mathrm{SO}_{4}^{-}$at $298 \mathrm{~K}$ and $(\square) \mathrm{SO}_{4}^{-}$at $333 \mathrm{~K}, \mathrm{pH} 2$. Potentials -0.8 to $-0.9 \mathrm{~V}$ for all except for $-1.4 \mathrm{~V}$ vs. SCE for sulphate solution at $333 \mathrm{~K}$. Initial solution; 10 ppm $\mathrm{Pb}$ (II) for all except $14 \mathrm{ppm}$ for sulphate solution at $333 \mathrm{~K}$. Mean linear flow velocity $0.088 \mathrm{~m} \mathrm{~s}^{-1}$ [22].

was an option to improve process performance and higher temperatures to improve the electrolysis in sulphate medium. The use of electrochemical techniques would allow results as good as those reported for precipitation technology for the removal of $\mathrm{Pb}$ (II) to be achieved.

Czerwiski and Żelazowska $[23,24]$ examined the deposition of $\mathrm{Pb}(\mathrm{II})$ on $\mathrm{RVC}$ from acidic and basic solutions. The electrochemical behaviour of lead deposited onto platinised RVC was reported to resemble that of metallic lead. They concluded that RVC was a very good matrix for lead deposition and that in acidic conditions, some influence on the electrochemistry of deposited lead from the matrix material (platinum) had been observed. Brennsteiner et al. [50] used 100 ppi RVC electrodes in a flow-through configuration to compare RVC with other novel forms of carbon, the results showed improved performance of RVC against the other materials. Widner et al. [51] used 20, 45, 60 and 80 ppi RVC electrodes in a flow-through configuration for the electrolytic removal of $\mathrm{Pb}(\mathrm{II})$ at flow rates between 60 and $2401 \mathrm{~h}^{-1}$. The potentials at which the reduction was mass transport controlled were determined in borate + nitrate solution on a vitreous carbon rotating disc electrode. The concentration of $\mathrm{Pb}$ (II) was depleted from $43 \mathrm{ppm}$ to $<0.5 \mathrm{ppm}$ in $800 \mathrm{~s}$ using a $80 \mathrm{ppi} \mathrm{RVC}$ electrode at $2401 \mathrm{~h}^{-1}$ with a current efficiency of $14 \%$. The concentration was $<0.1 \mathrm{ppm}$ after $20 \mathrm{~min}$ to $2 \mathrm{~h}$ electrolysis, depending on the RVC porosity and flow rate.
Carreño et al. [52] examined the influence of anions such as $\mathrm{Cl}^{-}, \mathrm{NO}_{3}^{-}$and $\mathrm{SO}_{4}^{-}$ions during the deposition of $\mathrm{Pb}$ (II) on an $\mathrm{RVC}$ electrode from aqueous solution. As in previous works [22], they reported higher removal efficiencies in chloride electrolytes than in sulphate electrolyte. They proposed fractured vitreous carbon (FVC) as a model surface to study the morphology of the deposits on the RVC electrodes by atomic force microscopy.

\subsection{Zinc deposition}

Zinc is used both in the electroplating industries and in the production of high power density batteries. These applications offer challenges both in electrode production and in effluent treatment. Lanza and Bertazzoli [53] for example, proposed a flow-through cell for the removal of zinc both from synthetic and industrial effluents. In the mass-transport control region with an $80 \mathrm{ppi}$ $\mathrm{RVC}$ electrode at $1201 \mathrm{~h}^{-1}$ flow rate, the $\mathrm{Zn}(\mathrm{II})$ concentration was depleted from 50 to $0.1 \mathrm{mg} 1$ within $20-40$ min, depending on $\mathrm{RVC}$ porosity, flow rate and $\mathrm{pH}$. With an industrial effluent, zinc removal was under mass transport control only within the $1.5 \mathrm{~mm}$ below the electrode surface; deeper in the electrode, the reaction was under mixed control; this was attributed to the poor conductivity of the electrolyte. In another paper, a segmented porous flow-through electrode was used for the separation of mixtures of $\mathrm{Cu}(\mathrm{II}), \mathrm{Ni}(\mathrm{II}), \mathrm{Zn}(\mathrm{II}), \mathrm{Ag}(\mathrm{I})$ and $\mathrm{Cd}(\mathrm{II})$ with an $\mathrm{RVC}$ reactor [54]. Electrodeposition rates were not dependent on flow rate or RVC porosity, but were dependent on $\mathrm{pH}$. The multi-stage $\mathrm{RVC}$ reactor successfully separated ternary mixtures of $\mathrm{Ag} / \mathrm{Cu} / \mathrm{Zn}$ and $\mathrm{Cu} / \mathrm{Cd} / \mathrm{Zn}$.

\subsection{Cadmium deposition}

A very poisonous heavy metal with strong cumulative effect in living systems, its discharge limits have been continuously lowered over recent years. Its removal from effluent streams has been considered in conjunction with other metals by several authors [54]. As well as determining $\mathrm{Pb}(\mathrm{II})$, Berrettoni et al. [48,49] used a mercury-plated RVC disk and cylinder electrodes to determine traces of $\mathrm{Cd}(\mathrm{II})$ through staircase voltammetric stripping analysis. Similarly, Brennsteiner et al. used a flow-through small-scale electrolytic cell for the removal of $\mathrm{Cd}(\mathrm{II})$, among other metals, on a series of conductive carbons, including RVC [50]. The RVC electrode was satisfactory for Cd(II) removal. Cadmium was removed up to $16 \%$ and $50 \%$ when the electrode was held at 0 and $-1 \mathrm{~V}$ vs. $\mathrm{Ag} \mid \mathrm{AgCl}$, respectively.

A laboratory scale electrolytic flow-by cell with an RVC cathode permitted the purification of aqueous solutions containing cadmium ions from 200 to $0.1 \mathrm{ppm}$, 
with current efficiencies up to $40 \%$, in 85 min of operation in a mass transport regime [55].

\subsection{Deposition of other metals}

There are a large number of other metal ions that appear in industrial effluents, however, not all of them have received attention regarding their recovery by RVC electrodes. Some of them are silver, vanadium and molybdenum. Silver is particularly important in effluents from photographic processes and as is the case with many other metals, its recovery offers environmental and economic benefits. Besides copper and lead, Wang and Dewald [18] also examined the deposition of $\mathrm{Ag}(\mathrm{I})$ with a flow-through RVC electrode. Like copper, the depositions were discontinuous, with regions of RVC left bare. Henry and Van Lierde used an electrochemical ion exchange process employing an RVC cathode, having pores filled with an ion exchange resin loaded with $\mathrm{V}$ and Mo from a hydrodesulphurisation process. They used a three-compartment electrode cell, in order to elute the co-adsorbed vanadium and molybdenum selectively [56]. This technique was first used for decontamination of nuclear wastes. Their results showed $93 \%$ and $7 \%$ vanadium and molybdenum recovery, respectively, at $323 \mathrm{~K}$ using $30 \mathrm{~g}^{-1} \mathrm{H}_{2} \mathrm{SO}_{4}$ eluant. The use of lower temperatures, constant current density, and more acidic eluants were all shown to decrease elution selectivity of vanadium towards molybdenum.

González and co-workers [57] studied the problems associated with the recovery of low concentrations of silver when high concentrations of copper and cyanide exist in solution. This is a typical problem found in the mining industry where cyanide baths are the most common leaching agents. Chemical speciation, cyclic voltammetry and the electrolysis of a cyanide solution containing $\mathrm{Ag}, \mathrm{Cu}$ and $\mathrm{CN}^{-}$showed that high $\mathrm{Cu}(\mathrm{II})$ and $\mathrm{CN}^{-}$concentration do not interfere in the selective deposition of silver. The electrochemical reduction of chromate ions has received increased attention; $\mathrm{Njau}$ and Janssen compared the performance of several threedimensional cathode electrode materials such as a packed bed of graphite particles, activated carbon, RVC, expanded titanium mesh and graphite felt. RVC and expanded titanium were found to passivate when in contact with chromate ions solution and, therefore, were not suitable for the reduction of chromate ions. However, the concentration of chromate could be decreased below $0.5 \mathrm{ppm}$ using the other cathode materials [58].

\section{Synthesis of organics}

The stability and inertness of $\mathrm{RVC}$ in a wide range of acids and bases can be exploited to produce a variety of organic compounds with better selectivity than other production routes. Mattiello and Rampazzo [59] described the electrochemical synthesis of $9.9^{\prime}$-spirobifluorene derivatives using an RVC electrode. They described their redox properties in terms of voltammetric responses. The electrolysis of the derivates modifies the RVC electrode by an olygomeric-polymeric structure. On the other hand, Szánto et al. [60] used the FM01-LC electrolyser (INEOS Chlor-Chemicals), to evaluate the electrosynthesis of coumestan and catecholamine derivatives on several electrodes. The performance of 30, 60 and 100 ppi RVC was compared with that of porous three-dimensional nickel electrodes. Both 30 and 60 ppi RVC were found to perform indifferently, while the 100 ppi RVC had a performance comparable to the nickel stacked net. Conversion efficiencies for the oxidation of catechol were around $80 \%$. However, the formation of a polymeric film reduced the efficiency and proved difficult to remove. Vaudano and Tissot [61] investigated the anodic production of $p$ isopropylbenzaldehyde ( $p$-cuminal) in both flowthrough RVC and cylindrical graphite cells. High rotation speeds and high flow rates increased selectivity up to $35 \%$ for RVC and $60 \%$ for graphite; conversion was $>95 \%$ at both electrodes. Krische and co-workers investigated the reduction mechanism of phenyl substituted bis(enone) in $0.1 \mathrm{M} \mathrm{LiClO}_{4}$ in $\mathrm{CH}_{3} \mathrm{CN}$, on a vitreous carbon electrode. The starting material was consumed and the current felt to nearly zero when only $30 \%$ of the theoretically required electrical charge had been passed. However, the overall yield was $76 \%$ with other polymeric products accounting for the mass balance. The authors proposed a mechanism involving the cycloaddition of an anion radical as an intermediate [62].

\section{Fenton's reagent and peroxide production}

There has been a great interest in the electrogeneration of hydrogen peroxide by the reduction of oxygen in solution, as it can be produced in situ at high selectivity and efficiency. Today, Fenton's Reagent is used to treat a variety of industrial wastes containing a range of toxic organic compounds [63]. The chemistry of the reagent can be represented as follows:

$$
\begin{aligned}
& \mathrm{Fe}^{2+}+\mathrm{H}_{2} \mathrm{O}_{2} \rightarrow \mathrm{Fe}^{3+}+\mathrm{OH}^{-}+\cdot{ }^{\bullet} \mathrm{OH} \\
& \mathrm{Fe}^{3+}+\mathrm{H}_{2} \mathrm{O}_{2} \rightarrow \mathrm{Fe}^{2+}+\cdot \mathrm{OOH}+\mathrm{H}^{+}
\end{aligned}
$$

Ponce de León and Pletcher [64] investigated the removal of formaldehyde from aqueous solutions via oxygen reduction in an RVC cathode cell, in an alkaline medium. The current-potential curves for an air saturated $1 \mathrm{M} \mathrm{NaOH}$ solution showed two waves (at $E_{1 / 2}=-460$ $\mathrm{mV}$ and $E_{1 / 2}=-970 \mathrm{mV}$ vs. SCE), attributed to the 
formation of $\mathrm{H}_{2} \mathrm{O}_{2}$ and $\mathrm{H}_{2} \mathrm{O}$, respectively. This was confirmed by controlled potential electrolysis. The concentration of $\mathrm{H}_{2} \mathrm{O}_{2}$ in the catholyte increased linearly with time during the electrolysis and the current efficiency decayed from $>90 \%$ to $57 \%$ at -0.6 and $-1.4 \mathrm{~V}$ vs. SCE, respectively. The reaction of $\mathrm{H}_{2} \mathrm{O}_{2}$ with formaldehyde produced either formic acid or carbon dioxide using an iron salt as catalyst to generate the Fenton's reactant during the electrolysis of $\mathrm{O}_{2}$ at $-0.6 \mathrm{~V}$ vs. SCE. The experiment was carried out with three different formaldehyde concentrations, 5, 13 and $116 \mathrm{ppm}$. In all cases, the formaldehyde concentration decreased below 1 ppm; however, the removal of formaldehyde was not mass transport controlled as it was limited by the rate of formation of hydrogen peroxide, hence by the supply of oxygen to the electrode surface and the kinetics of the reduction of oxygen at the $\mathrm{RVC}$ electrode surface. The results indicated that adding a trace of iron salt could treat effluents and, if needed, a small amount of an electrolyte, e.g., $\mathrm{NaCl}\left(+\mathrm{FeCl}_{2}\right)$ in an acidic media, to achieve the oxidation of formaldehyde to $\mathrm{CO}_{2}$. During the oxidation of $13 \mathrm{ppm}$ of formaldehyde in an acidic media with added $\mathrm{FeCl}_{2}$, the total organic carbon (TOC) dropped from 6.8 to $1.3 \mathrm{mg} \mathrm{dm}^{-3}$, indicating substantial oxidation of formaldehyde to carbon dioxide.

In a following paper, Alvarez-Gallegos and Pletcher [65] reported current efficiencies between $40 \%$ and $70 \%$ for the electro-synthesis of $\mathrm{H}_{2} \mathrm{O}_{2}$ in aqueous acidic solutions in a similar cell. The presence of $\mathrm{Fe}(\mathrm{II})$ in the catholyte reduced the half-life of $\mathrm{H}_{2} \mathrm{O}_{2}$ down to minutes. At $\mathrm{pH} \mathrm{2,} \mathrm{the} \mathrm{RVC} \mathrm{electrode} \mathrm{was} \mathrm{found} \mathrm{to} \mathrm{be}$ suitable to oxidise organic compounds. Further investigations by the same authors focused on the removal of phenols and related compounds in the presence of $\mathrm{Fe}(\mathrm{II})+\mathrm{H}_{2} \mathrm{O}_{2}$ in aqueous solutions at $\mathrm{pH} 2$ [66]. Aromatic molecules such as dyes between 0.1 and $1 \mathrm{mM}$ concentrations were completely oxidised and their chemical oxygen demand (COD) was reduced to insignificant levels at a current efficiency above 50\%. Fig. 11 shows the decay in COD for different organic molecules reported by the authors at an initial concentration of $0.33 \mathrm{mM}$. The authors estimated, that in a suitable cell design the treatment of $0.33 \mathrm{mM}$ phenol solution would require $1.25 \mathrm{~kW} \mathrm{~h} \mathrm{~m}^{-3}$ to reduce the COD to below 10 ppm. They suggested that higher rates of destruction would be possible with a gas diffusion electrode, or indeed by increasing the size of the RVC or applying a more negative potential than $-700 \mathrm{mV}$ vs. SCE value used in the experiments.

Huissoud and Tissot [67,68] published two papers investigating the production of $\mathrm{H}_{2} \mathrm{O}_{2}$ by the intermediate reduction of 2-ethyl-9,10-anthraquinone (EAQ) on 45, 60 and 80 ppi RVC electrodes at current densities between 05 and $0.8 \mathrm{~mA} \mathrm{~cm}{ }^{-2}$. Current efficiencies around $50 \%$ as well as hydrogen evolution were reported for all runs, but over $0.9 \mathrm{~mA} \mathrm{~cm} \mathrm{~cm}^{-2}$ current

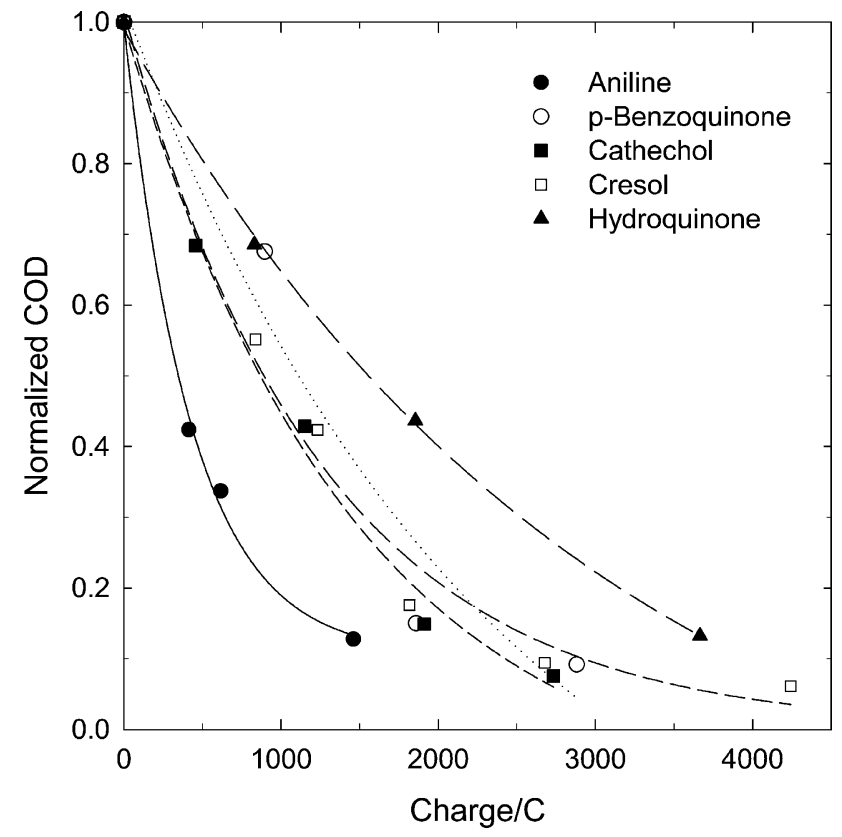

Fig. 11. Chemical oxygen demand (COD) as a function of charge passed for electrolyses of different organic compounds at $0.33 \mathrm{mM}$ concentration in $0.05 \mathrm{M} \mathrm{Na}_{2} \mathrm{SO}_{4}+1 \mathrm{mM} \mathrm{Fe}$ (II) solution at $\mathrm{pH} 2$ in a membrane cell with a RVC electrode. Cathode potential $-0.70 \mathrm{~V}$ vs. SCE, mean linear velocity of the catholyte of $0.13 \mathrm{~m} \mathrm{~s}^{-1}$ at room temperature [66].

density, $\mathrm{H}_{2} \mathrm{O}_{2}$ was reduced rapidly, as its concentration was high. The generation of $\mathrm{H}_{2} \mathrm{O}_{2}$ was more efficient in the presence of EAQ. In the second paper Huissoud and Tissot [68] examined the production of alkaline $\mathrm{H}_{2} \mathrm{O}_{2}$ by intermediate electro-reduction of EAQ in a flow-by RVC electrode in two-phase liquidliquid flow. The two-phase electrolyte used was a mixture of tributylphosphate (TBP) and diethylbenzene (DEB) as the organic phase and $\mathrm{NaOH}$ as the aqueous phase. They investigated the influence of current, flow rate, EAQ concentration in the organic phase, organic/ aqueous phase volume ratio and RVC grade on the process. A new method of producing alkaline hydrogen peroxide was developed in the intermediate electro-reduction of EAQ in a two-phase medium on an $\mathrm{RVC}$ cathode in the presence of oxygen. Current efficiencies were $85 \%$ and $\mathrm{H}_{2} \mathrm{O}_{2}$ concentration reached 0.8 $\mathrm{M}$. The results showed that current efficiency was favoured at low organic/aqueous phase volume ratios and one-step electrolysis was more efficient than twostep electrolysis.

Gyenge and Oloman [69] studied the influence of cationic, non-ionic and anionic surfactants, on the reduction of $\mathrm{O}_{2}$ to $\mathrm{H}_{2} \mathrm{O}_{2}$ in $\mathrm{Na}_{2} \mathrm{CO}_{3}$ and $\mathrm{H}_{2} \mathrm{SO}_{4}$ electrolytes on a 30-ppi $\mathrm{RVC}$ electrode. They found that the surfactant Aliquant 336 tricaprylmethylammonium chloride increased the rate of $\mathrm{O}_{2}$ reduction to $\mathrm{H}_{2} \mathrm{O}_{2}$ in both electrolytes due to the well-organized surfactant 
structures formed on the surface of the electrode. However, the non-ionic and anionic surfactants Triton $\mathrm{X}$ and sodium dodecyl sulphate, respectively, retarded the reduction of $\mathrm{O}_{2}$ to $\mathrm{H}_{2} \mathrm{O}_{2}$ as they formed less organized surface aggregates that blocked the access of $\mathrm{O}_{2}$ to the electrode. They achieved 0.31 and $0.26 \mathrm{M}$ peroxide concentration in $\mathrm{Na}_{2} \mathrm{CO}_{3}$ and $\mathrm{H}_{2} \mathrm{SO}_{4}$, respectively, at current efficiencies of $61 \%$ and $55 \%$, respectively. Without surfactant, the concentration of $\mathrm{H}_{2} \mathrm{O}_{2}$ was 0.07 and $0.014 \mathrm{M}$ with $14 \%$ and $7 \%$ current efficiency in the acid and alkaline electrolytes, respectively.

\section{Batteries and fuel cells}

Since the early 1980 s, researchers have reported the use of RVC as an electrode material for different batteries [70]. The inertness, high current densities and the high temperature resistance of RVC make it worthwhile to consider it for fuel cell design [71]. Iacovangelo and Will [72] studied current density, flow rate, electrolyte composition, substrate thickness and pore size of zinc deposits on RVC electrodes, with the aim of using them as substrates in $\mathrm{Zn}$ batteries. They found that high electrolyte flow rates and thicker foams produced uniform $\mathrm{Zn}$ deposits. The best results were obtained with 2 $\mathrm{mm}$ thick 100 ppi RVC at flow rates with Reynolds numbers close to 500. An organic dendrite inhibitorsolubiliser helped to produce dendrite free $\mathrm{Zn}$ deposits inside the RVC structure, allowing current densities of $100 \mathrm{~mA} \mathrm{~cm}^{-2}$.

Mastragostino and Valcher [5] used 60 and 100 ppi $\mathrm{RVC}$ electrodes as supports for a polymeric salt as bromine complexing agent in a $\mathrm{Zn}-\mathrm{Br}_{2}$ battery. The large surface area of RVC helped to overcome difficulties related to low current density while its porosity also helped to retain the solid complex of bromide that was generated during the charging stage. Increasing the amount of $\mathrm{PBr}$ at constant RVC thickness or decreasing the RVC thickness while keeping the amount of $\mathrm{PBr}$ constant impaired battery performance. The best performance was reported for $100 \mathrm{ppi}$ RVC. The charge/discharge experiments carried out to evaluate the performance of the zinc-bromine battery with a $\mathrm{RVC} / \mathrm{PBr}$ electrode showed near constant charging potential over the entire charge period, while the discharging potential decreased slightly while discharging at constant current. Tests to determine the self-discharge rate, a key parameter in battery construction, found it to be only $0.01 \mathrm{~A} \mathrm{dm}^{-2}$ at $298 \mathrm{~K}$. Overall, the authors saw the results as a promising starting point for future investigations.

Tsutsumi et al. [73] used a polyaniline (PANI)poly( $p$-styrenesulfonic acid) (PSS) modified RVC electrode in a rechargeable lithium battery. A coulombic efficiency of about $60 \%$ under high current density cycling conditions (3.8 $\mathrm{A} \mathrm{g}^{-1}$ per gram electrode) was reported for the $\mathrm{Li} / \mathrm{LiClO}_{4}$ cell using the PANI-PSS modified RVC electrode. Further application of the PANI-PSS composites in this system was made dependent on optimisation of the current density and the amount of modified PANI-PSS composite on the RVC electrode.

More recently, Gyenge et al. [74] reported the use of electroplated RVC substrates with a $\mathrm{Pb}-\mathrm{Sn}(1 \mathrm{wt} \%)$ alloy as current collectors for lead-acid batteries. Several electrochemical techniques were used to evaluate the current collectors. A battery with a $137 \mathrm{~cm}^{2}$ current collector completed 500 cycles and over $1500 \mathrm{~h}$ of continuous operation. The results indicated that electroplated $\mathrm{RVC}$ is a promising material for the development of lower weight lead-acid batteries with RVC current collectors. RVC has also been used to study the kinetics of redox couples with the aim of use in storage redox flow cell batteries: together with other carbon base electrodes, Chong and Skyllas-Kazacos [75] determined the kinetic parameters of the $\mathrm{V}(\mathrm{V}) / \mathrm{V}(\mathrm{IV})$ couple. Mastragostino and Gramellini [76] studied the electrochemical processes of the aqueous $\mathrm{Br}_{2} / \mathrm{Br}^{-}$system using a rotating disc electrode both at reticulated and solid vitreous carbon. On both electrodes, the cathodic and the anodic processes involve two consecutive electrochemical steps. The $\mathrm{Br}_{3}^{-}$reduction occurs via formation of $\mathrm{Br}_{2}$, with which $\mathrm{Br}_{3}^{-}$is in rapid equilibrium, whereupon $\mathrm{Br}_{2}$ is reduced.

\section{Other applications}

Wauters and Winnick [77] used an electrolytic membrane to recover bromine from waste hydrogen bromide streams, the system being based on a molten salt saturated membrane with RVC gas-diffusion electrodes. Experiments at $573 \mathrm{~K}$ and process stream concentrations from $25 \%$ to $75 \%$ hydrogen bromide at flow rates of $50-300 \mathrm{ml} \mathrm{min}-1$ showed a fractional conversion of reactant as high as $95 \%$.

RVC has been used in a number of other applications, including: (a) a cathode in cathodoluminescent light source applications [78], (b) in reactor shutdown, decontamination, and decommissioning activities of nuclear reactors for the removal of Cs-137 inside a pressure vessel [79], (c) as an electrode contact in an innovative food powered mobile robot that uses a microbial fuel cell (MFC) system to convert carbohydrate fuel to an electrical power source [80], (d) as a plasma generator in a 10 torr pressure microwave [81] and (e) as an electrode in gas-phase pulsed streamer corona reactors for the removal of $\mathrm{NO} / \mathrm{NO}_{x}$ from the exhaust of a 5 $\mathrm{kW}$ diesel engine [82]. 


\section{Summary}

Over the past 30 years, the design of electrochemical cells and reactors has been influenced by the availability and ability to shape different types of material to a particular cell or reactor $[2,83]$. RVC has contributed, continuing to be used as a model electrode in the design and construction of new electrochemical cell designs, both in fundamental and applied electrochemistry. This paper has pointed out the following examples of current and developing applications that use RVC as an electrode material, including: electrochemical cell design: flow-by, flow through, and rotating cylinder and disc electrodes, sensors, metal ion removal: copper, lead, zinc, cadmium, silver, organic synthesis, Fenton's reagent and hydrogen peroxide production and batteries and fuel cells.

A number of advantages of RVC can be highlighted in these examples, such as: easy construction and handling, strong chemical and heat resistance, and high volume/area ratio. Drawbacks of RVC include (a) it is fragile and cannot withstand high mechanical loads and (b) it requires skill from the experimentalist in order to make the appropriate electrical connection with the electrode feeder. Some of the driving forces that will influence the use of RVC in the future will be its low price compared to other electrode materials and its ability to fit in a more compact and modular reactor design. RVC will continue complementing other types of reticulated material such as copper, nickel, and aluminium together with carbon felt. Future developments are anticipated in the areas of effluent treatment, electroanalytical sensor detection and energy conversion cells.

RVC materials can be modified by metal and conductive organic coatings and by impregnation of organic, inorganic and biochemical species. It is also possible to produce RVC type materials having a controlled content of metal (or metal compound) catalysts [84]. Such coating and surface modification/impregnation techniques allow the applications of RVC to be considerably extended and diversified.

\section{References}

[1] A. Tentorino, U. Casolo-Ginelli, J. Appl. Electrochem. 8 (1978) 195.

[2] D. Pletcher, F.C. Walsh, in: J.D. Genders, N.L. Weinberg (Eds.), Electrochemical Technology for a Cleaner Environment, The Electrosynthesis Co, Lancaster, New York, 1992, p. 51.

[3] J. Wang, Electrochim. Acta 26 (1981) 1721.

[4] M.G. Wickham, P.H. Cleveland, P.S. Binder, P.H. Akers, Ophthalmic Res. 15 (1983) 116

[5] M. Mastragostino, S. Valcher, Electrochim. Acta 28 (1983) 501.

[6] U. Fischer, R. Saliger, V. Bock, R. Petricevic, J. Fricke, J. Porous Mater. 4 (1997) 281.

[7] W.C. Moss, Appl. Therm. Eng. 18 (1998) XXIV.
[8] Y. Aoki, PhD Thesis, University of Bath, 1993.

[9] Electrolytica, Inc. 87 Westwind, Lane, Amherst, NY 14086, http:// www.electrolytica.com/index.htm [10-07-2003].

[10] I. Whyte, PhD Thesis, Southampton University, 1991.

[11] Energy Research and Generation, Inc. Available from http:// www.ergaerospace.com/index.htm [10-07-2003].

[12] F.C. Walsh, A First Course in Electrochemical Engineering, Electrochemical Consultancy, Romsey, UK, 1993.

[13] D.J. Pickett, Electrochemical Reactor Design, second ed., Elsevier, Amsterdam, 1979.

[14] D. Pletcher, F.C. Walsh, Industrial Electrochemistry, second ed., Chapman \& Hall, London, 1990.

[15] A.N. Strohl, D.J. Curran, Anal. Chem. 51 (1979) 353.

[16] A.N. Strohl, D.J. Curran, Anal. Chem. 51 (1979) 1045.

[17] A.N. Strohl, D.J. Curran, Anal. Chem. 51 (1979) 1050.

[18] J. Wang, H.D. Dewald, J. Electrochem. Soc. 130 (1983) 1814.

[19] H.D. Dewald, J. Wang, Anal. Chim. Acta 166 (1985) 163.

[20] S. Langlois, F. Coeuret, J. Appl. Electrochem. 19 (1989) 43.

[21] S. Langlois, F. Coeuret, J. Appl. Electrochem. 20 (1990) 740.

[22] C. Ponce de León, D. Pletcher, Electrochim. Acta 41 (1996) 533.

[23] A. Czerwiski, M. Żelazowska, J. Electroanal. Chem. 410 (1996) 55.

[24] A. Czerwiski, M. Żelazowska, J. Power Sources 64 (1997) 29.

[25] J. Wang, H. Dewald, Anal. Chim. Acta 136 (1982) 77.

[26] W.J. Blaedel, J. Wang, Anal. Chem. 51 (1979) 799.

[27] W.J. Blaedel, J. Wang, Anal. Chem. 52 (1980) 1697.

[28] G.W. Reade, PhD Thesis, University of Portsmouth, UK, 1996.

[29] V.E. Norvell, G. Mamantov, Anal. Chem. 49 (1977) 1470.

[30] P.A. Flowers, M.A. Maynor, D.E. Owens, Anal. Chem. 74 (2002) 720.

[31] M.A. Lange, J.Q. Chambers, Anal. Chim. Acta 175 (1985) 89.

[32] H.J. Wieck, C. Shea, A.M. Yacynych, Anal. Chim. Acta 142 (1982) 277.

[33] H.J. Wieck, G.H. Heider Jr., A.M. Yacynych, Anal. Chim. Acta 158 (1984) 137.

[34] A.M. Yacynych, S.V. Sasso, G.H. Heider, H.J. Wieck, Proc. Symposium on Sensor Science \& Technology, vol. 87, 6-8 Apr. 1987.

[35] G.H. Heider, S.V. Sasso, K. Huang, A.M. Yacynych, H.J. Wieck, Anal. Chem. 62 (1990) 1106.

[36] T.P. Tougasand, D.J. Curran, Anal. Chim. Acta 161 (1984) 325.

[37] P. Jaraba, L. Agu, P. Yanez-Sedeno, J.M. Pingarron, Electrochim. Acta 43 (1998) 3555.

[38] S.B. Saidman, J.B. Bessone, Electrochim. Acta 45 (2000) 3151.

[39] P. Hrníová, F. Opekar, K. Tulik, Sensors and Actuators B 69 (2000) 199.

[40] F.C. Walsh, D. Pletcher, I. Whyte, J.P. Millington, J. Chem. Tech. Biotechnol. 55 (1992) 147.

[41] D. Pletcher, I. Whyte, F.C. Walsh, J.P. Millington, J. Appl. Electrochem. 21 (1991) 667.

[42] D. Pletcher, I. Whyte, F.C. Walsh, J.P. Millington, J. Appl. Electrochem. 23 (1993) 82.

[43] F.C. Walsh, Bull. Electrochem. 8 (1992) 471.

[44] E.J Podlaha, J.M. Fenton, J. Appl. Electrochem. 25 (1995) 299.

[45] A.M. Polcaro, S. Palmas, M. Mascia, F. Renoldi, R.L. Correa dos Santos, Ind. Eng. Chem. Res. 38 (1999) 1400.

[46] J.D. Fisk, J.D. Boyle, Trans. IMF 78 (2000) 113.

[47] Lead, Biol. Inform. Available from http://www.webelements.com/ webelements/elements/text/Pb/biol.html [10-07-2003].

[48] M. Berrettoni, S. Zamponi, R. Marassi, A. Czerwinski, Anal. Chim. 76 (1986) 171.

[49] S. Zamponi, M. Berrettoni, R. Marassi, Anal. Chim. Acta 219 (1989) 153.

[50] A. Brennsteiner, J.W. Zondlo, A.H. Stiller, P.G. Stansberry, D. Tian, Y. Xu, Energy Fuels 11 (1997) 348.

[51] R.C. Widner, M.F.B. Sousa, R. Bertazzoli, J. Appl. Electrochem. 28 (1998) 201. 
[52] G. Carreño, E. Sosa, I. González, C. Ponce-de-León, N. Batina, M.T. Oropeza, Electrochim. Acta 44 (1999) 2633.

[53] M.R.V. Lanza, V. Bertazzoli, J. Appl. Electrochem. 30 (2000) 61.

[54] R. Suzuki, Wh. Li, M. Schwartz, K. Nobe, Plat. Surf. Finish. 82 (1995) 58.

[55] A.J.B Dutra, A. Espínola, P.P. Borges, Minerals Eng. 13 (2000) 1139.

[56] P. Henry, A. Van Lierde, Hydrometallurgy 48 (1998) 73.

[57] V. Reyes Cruz, M.T. Oropeza, I. González, C. Ponce-de-León, J. Appl. Electrochem. 32 (2002) 473.

[58] K.N. Njau, L.J.J. Janssen, J. Appl. Electrochem. 29 (1999) 411.

[59] L. Mattiello, L. Rampazzo, Electrochim. Acta 42 (1997) 2257.

[60] D. Szánto, P. Trinidad, F.C. Walsh, J. Appl. Electrochem. 28 (1998) 251

[61] F. Vaudano, P. Tissot, Electrochim. Acta 46 (2001) 875.

[62] Y. Roh, H.-Y. Jang, V. Lynch, N.L. Bauld, M.J. Krische, Org. Lett. 4 (2002) 611

[63] Industrial wastewater. Fenton's reagent, iron-catalysed hydrogen peroxide Available from http://www.h2o2online.com/applications/ industrialwastewater/fentonsreagent.html [10-07-2003].

[64] C. Ponce de León, D. Pletcher, J. Appl. Electrochem. 25 (1995) 307.

[65] A. Alvarez-Gallegos, D. Pletcher, Electrochim. Acta 44 (1998) 853.

[66] A. Alvarez-Gallegos, D. Pletcher, Electrochim. Acta 44 (1999) 2483.

[67] A. Huissoud, P. Tissot, J. Appl. Electrochem. 28 (1998) 653.

[68] A. Huissoud, P. Tissot, J. Appl. Electrochem. 29 (1999) 17.

[69] E.L. Gyenge, C.W. Oloman, J. Appl. Electrochem. 31 (2001) 233.
[70] IEEE History Centre. Volta's electrical battery invention, 1799. Available from http://www.ieee.org/organizations/history_center/ milestones_photos/volta.html [10-07-2003].

[71] NFCRC, National Fuel Cell Research Centre. Challenges cost reduction. Available from http://www.nfcrc.uci.edu/fcresources/ FCexplained/challenges.htm [10-07-2003].

[72] C.D. Iacovangelo, F.G. Will, J. Electrochem. Soc. 132 (1985) 851.

[73] H. Tsutsumi, S. Yamashita, T. Oishi, J. Appl. Electrochem. 27 (1997) 477.

[74] E. Gyenge, J. Jung, B. Mahato, J. Power Sources 113 (2003) 388.

[75] S. Zhong, M. Skyllas-Kazacos, J. Power Sources 39 (1992) 1.

[76] M. Mastragostino, C. Gramellini, Electrochim. Acta 30 (1985) 373.

[77] C.N. Wauters, J. Winnick, AIChE J. 44 (1998) 2144.

[78] A.G. Chakhovskoi, C.E. Hunt, G. Forsberg, T. Nilsson, P. Persson, C.E. Hunt, in: Proc. 14th International Vacuum Microelectronics Conference IVMC 2001, Piscataway, NJ, USA, pp. 263-264.

[79] K.J. Allen, P.B. Wells, O.G. Romanenko, I.L. Tazhibaeva, D.S. Newton, T. Zhantikin, Trans. Am. Nuclear Soc. 86 (2002) 71.

[80] S. Wilkinson, in: Proceedings of the IASTED International Conference Robotics and Applications, IASTED/ACTA Press, Anaheim, CA, USA, 2000, pp.176-181.

[81] S. Maeda, H. Matsuo, K. Kuwahara, Y. Matsuda, H. Kuwahara, H. Fujiyama, Surf. Coatings Technol. 97 (1997) 404.

[82] B.R. Locke, A. Ichihashi, H.K. Hyun, A. Mizuno, IEEE Trans. Industry App. 37 (2001) 715.

[83] F.C. Walsh, Pure Appl. Chem. 73 (2001) 1819.

[84] M. Turpin, Morgan Group Technology Ltd., July 2003, personal communication. 